\title{
I La Galigo's Theater Performance in Postmodern Aesthetic Review
}

\author{
A. Rahmaeni M, S.Pd ${ }^{1 *}$, Dr.Sumaryadi, M.Pd ${ }^{2 * *}$, Fitrya Ali Imran,M.Pd ${ }^{3 * * *}$ \\ Yogyakarta State University, Yogyakarta,Indonesia \\ *Corresponding author, Email: andirahmaeni7@gmail.comDr.Sumaryadi, M.Pd \\ **Corresponding author, Email: sumaryadi@uny.ac.id Fitrya Ali Imran,M.Pd \\ ***Corresponding author, Email: irafitrya@yahoo.com
}

\begin{abstract}
The arrival of contemporary theater performance art in Indonesia cannot be separated with the history of theater performance arts in various regions in Indonesia. The term "contemporary" refers to the current scope and time, as well as a way to indicate that there are developments and changes in theater. The I La Gligo performance is a part of a global art that is made possible in the contemporary theatrical elements. The global state of art, in the postdramatic framework, is a result of theater aesthetics that is in one breath with the globalization phenomenon. I La Galigo is one of the traditional cultural forms of South Sulawesi, which is also one of the longest literatures that inspires the performance that has been recognized by the UNESCO. It delivers the noble values of Indonesian culture such as courage, cultural diversity, as well as the shyness and empathy of the Indonesian people to the international stage. This study is aimed to identify the forms, contributing factors and meaning of the Indonesian postmodern practices through the I La Galigo theater that is directed by Robert Wilson. The findings suggest that in the concrete process of work in the postmodern culture, there is an aesthetic idiom that is developed through dance, visual forms, music, and poetry which are then manifested in the form of a theatrical performance that puts the emphasis on the use of gesture acting.
\end{abstract}

Keywords: Theater, I La Galigo, Global state, aesthetics, postmodern

\section{INTRODUCTION}

The development of the theater experienced turbulence can not be separated from the context of modernization, especially in the fields of philosophy, science, art and culture. Humans feel dissatisfied and unable to survive the development of science and technology, capitalism, and modern ways of thinking. This reality causes the thought of modernism to be obsolete and must be replaced with a new paradigm called postmodernism. "Postmodern emerges as a reaction to modern culture which is considered as a failure. It seems to improve, reject, end, or deconstruct modern culture while shaping itself into a new culture that is considered more meaningful" p.13-14 [9].

"Postmodernism is a shift of values that accompanies mass culture from production to consumption, from creator to receiver, from work to text, from artist to connoisseur. The shift also occurs from seriousness (intellectualism) to the values of the game (popular), from depth to surface, from universal to particular, the resurrection of aesthetic values, the emergence of political representations that oppose structure authority, and the revival of traditions, primordial, and values of other old societies "p.151 [4].There are several views that present postmodernism as something that is very important for the life of social society, namely: 1) postmodernism is a movement of ideas that replaces the ideas of modern times (which prioritizes ratio, objectivity, and progress); 2) postmodernism has ideals, wants to improve economic and social conditions, awareness of historical events and developments in religion, broadcasting arts and culture; 3) postmodernism is more populist because it removes the boundaries between high culture (high culture) and mass culture (mass / popular culture). p.22 [10].

Piliang explores the aesthetic idioms that dominate the color in postmodern art which can be noted, among others pastiche, parody, kitsch, camp and schizophrenia. Exploration that's not onlyreveals how exactly the aesthetic idioms is in a work of art, but at the same time it is relatively a categorization of the work as part, or a marker of postmodern art. Excavation, development, expansion, and application of these idioms can be a part of aesthetic development in the practice of postmodern art itself p.207-209 [5].

Theater as a performance art certainly has aesthetic values and is an accumulation of values that were conceived and communicated to the audience. These aesthetic values are located in each part before the performance, at the time of the performance, and after the performance when the performance has been enshrined in a media documentation.

This paper tries to express the five aesthetic idioms of postmodern art, after first understanding a work of theater performance art in the perspective of postmodernism. Aesthetic studies show structurally related to element fulfillment the aesthetics of the show. The theater performance art in question is Theater I La Galigo which 
isdirected by Robert Wilson after being adapted by Rhoda Grauer. It is a theater performance which script was adapted from Sureq Galigo, an epic about the myth of the creation of the Bugis tribe that was enshrined through oral traditions and texts.

Based on this view, researchers feel the need to conduct research on the aesthetics of postmodernism. From the description above, the research conducted uses a qualitative analytical-interpretative methodology. To explore the problem, it will use a postmodern aesthetic review to uncover each idiom pastiche, parody, kitsch, camp, and schizophrenia in theater performance works I La Galigo.

\section{DISCUSSION}

\section{A. PERFORMANCE OF THE I LA GALIGO THEATER}

Theater I La Galigo is a theater performance sourced from Sureq Galigo which is a literary work of legend that contains the origin of the creation of the land of Sulawesi. The structure of Galigo tells the origin of human presence on earth and the status system which is very important as a guide in Bugis human social life.

The book I La Galigo tells about the process of life originating from the upper worlds and the underworld which is the world of the gods and then a new world is born that is the middle world that does not yet contain any creature "What do Gods mean without human being to pray to the sky and the earth!” p, 20 [11]. Therefore Patotoqé the Most High who is a figure Gods sending his son Batara Guru to become the first human being on earth. Then Batara Guru used the power he had to create life in the Middle world, then he married the divine creature of the Underworld namely Nyiliq Timoq, there was a meeting of life in both the Upper and Lower Worlds, forming kingdoms and life on earth.

According to Koolhof's statement, the stories inside Sureq Galigo very little is known by Sulawesi people themselves, and it is reported that less than a hundred people are still alive who can read and understand the manuscript. There are no two identical manuscripts, but there are enough similarities in the content to show that various episodes can be ascribed to different poetic traditions, if not single authors p.140 [3].

Sureq Galigo is the longest literary work in the world written between the 13th to 15 th centuries consisting of 600 pages and 300 thousand lines longer than Mahabarata poetry and recognized as world heritage.

Theater performance I La Galigo first brought to the stage by Robert Wilson artist from Texas, United States. Wilson became interested in bringing up the literary work on stage since 2004 in Asia, Europe, Australia and the United States. Wilson's desire is also supported by enthusiasm Change Performing Arts and Bali Purnati Center for the Arts. The process that Wilson went through began by deepening with the cultural team of South Sulawesi culture who gave advice related to efforts to bring to life literary epics I La Galigo on stage.

Now, I La Galigo is not just a literary work which is a cultural artifact, but has been transformed into a theater performance I La Galigo which contains noble values has been recognized internationally.

\section{B. THE BIRTH OF AESTHETIC POSTMODERN}

Understanding aesthetics as an art philosophy through various civilizations from centuries. Since the time of Socrates (469-344 BC) the beginning concept of aesthetics was not known as science, then Plato (427-347 BC) known as the "aesthetic deity", denotes a time / school of thought which came to be known as art philosophy. Next, Alexander Gottlieb introduced the term aesthetic in 1714-1762 as a philosophical study of the perceptual beauty p.2 [7].

Understanding aesthetics as philosophy in principle has placed at one point the dichotomy between reality and abstraction, as well as between beauty and meaning. Aesthetics no longer listens to conventional beauty, but has shifted towards a discourse and phenomenon. Assess that the aesthetic practices of today are different from the aesthetic practices of the past which are progressive, rational, and serious. Now aesthetic practices turn to new approaches that are eclectic, irrational and ironic p.65 [1].

Aesthetics, in the philosophy of art, is an approach to art that abstracts particular aspects of a work to arrive at conclusions about universal problems in art. Aesthetics also inherit the branch of philosophical studies namely ontology of art which is a philosophical study of the nature of works of art, epistemology of art is a philosophical study of the knowledge process that underlies the creation of works of art social philosophy of art which is a philosophical study of the relationship between art and society p.735-736 [7].

Postmodrnism aesthetics, as demonstrated by Hal Foster in Postmodern Culture are forms of subversion of the standard rules of aesthetic modernism. Post means after and modern means modernity, then the presence of postmodern gives a signal to the modern era of criticism and constructive and destructive efforts towards thinking that develops in the modern era p.43 [8].

Postmodernism is a school that opposes all the perfections of Modernism, often even opposing existing rules and combining various styles. Modern culture is considered to experience a failure in its visualization strategy that is uniform and boring. Postmodern creates a more independent society in its own style.

The aesthetics in postmodern discourse no longer compare the beauty of one with another; which one is moral, which one is immoral. But aesthetic discourse of postmodern now it looks for the ugliest among the ugly. The aesthetics of postmodern also no longer distinguish what is visible, what is hidden. The aesthetics of postmodern looking for the more hidden among the most hidden p.185 [2].

Posmodern aesthetic symptoms or tendencies can also be found in the realm of theater, especially we can understand that theater is part of art. In his book entitled Cultural Hyperreality, Yasraf Amir Pilliang revealed "at least five idioms that are quite dominant characterize postmodern aesthetics, namely (1) pastiche, (2) parody, (3) kitsch, (4) camp, and (5) schizophrenia "P.149 [6]. The five postmodern 
aesthetic idioms are summaries of various experts who have different views. Piliang summarizes the explanations of the experts while affixing his own opinions so that he succeeds in formulating the five idioms as an aesthetic feature of postmodernism.

\section{POSTMODERN AESTHETIC IDIOMS IN THE I LA GALIGO TEACHER PERFORMANCE}

Theater show I La Galigo which lasts 2 and a half hours is a work that has aesthetic complexity. The complexity can be seen from various references that build the idiom contained in the show. Next, the related references of idioms in the show will be explained that can express a picture of a postmodern aesthetic.

\section{1) Pastiche}

Pastiche referred to as works that contain loan elements and in this case works pastiche very much depends on past works and previous aesthetic idioms. Pastiche work is a pure imitation without any pretense, the principle is more to the existence of equality and interconnection. Texts of pastiche imitating past texts in order to lift and appreciate them p.188 [5]. Pastiche characteristics emerge when a text may mimics or imitate other literary works or previous works. "As pure imitation, pastiche imitating past texts as an effort to lift and appreciate them, by removing them from the spirit of his day, and bring it into context the spirit of the times present day p.210 [5].

Patronization of pastiche to the canons of the past, according to Piliang, caused by the diversity factor p.212 [5]. One such patronization is referred to as Umberto Eco reconstruction realism, is pure replicas or duplications of past cultures or works p.212 [5], while Charles Jenks distinguishes between concepts historicalism, as the combination of various elements, styles or subsystems (existing in the previous context) used in a new synthesis, and revivalism that is, as a "form of substitution, the taking over of the position of a period which is maintained, not in the form of creative continuity from tradition, nor pure duplication" p.212 [5].

Based on the concept exposure pastiche can be concluded that the presence of the Theater I La Galigo performance and its development is a form of idiom usage pastiche. Among them, because of the nature of pastiche is the use of a past culture in order to appreciate that culture, not as a goal of mobilizing political ideology or a critical form of a culture.

An epic originating from South Sulawesi's speech culture. From oral tradition, the notes are then lifted onto the stage of the performance into a theater performance in order to revive and appreciate it. This is in line with the concept of social dynamics that all processes of upheaval that lead to social change with historical motives that drive towards the achievement of a new balance equal to the conditions and conditions of the times.

Postmodern aesthetics in the I La Galigo show related to the sociology of society in the postmodern era. Postmodern borrowed and used signs from the classical and modern periods, not to uphold its ideological and spiritual meanings, but to create new signs by abandoning conventional meanings [2].

Theater I La Galigo lift the aesthetic text or language form from historical fragments, and re-lift the spirit of past works to the present, although the big idea in the show is viewed from a western perspective, but the elements in it are Indonesian culture, from South Sulawesi.

\section{2) Parody}

Parody aims to express feelings of dissatisfaction, displeasure, discomfort with the intensity of the style or past work referred. In this case parody becomes a kind of opposition or contrast between various texts, works, or styles that are confronted with texts, works, or other styles with the intention of insinuating or making jokes from him p.190-191 [5].

In the show I La Galigo which raises the story of Sawerigading romance there are many social criticisms including values Siri 'na Passe transformed in Sawerigading applying scenes which were rejected by We Cudaiq. Where siri ' is a very decisive concept in the identity of the Bugis and the people of South Sulawesi in general. Concept siri ' refers to feelings of shame and pride whereas pessé/Pacce refers to an awareness and feeling of empathy for the suffering felt by each member of the community. In this proposal, Sawerigading brings various kinds in accordance with sacred rituals together with his troops who are in a flawed and ridiculous condition, this illustrates that Sawerigading came to bring himself and all the deficiencies he had. The aesthetic form of the parody can be seen through the form of the offerings brought in and the ritual form which is indeed different. The form of offering which was brought in the form of gold pendants larger than those possessed by the reference. In real life, the size of a gold pendant is only about $5 \mathrm{~cm}$ in diameter or as wide as the maximum range a human finger can hold, vice versa in this scene is giant sized. In addition to differences in the size of the pendant, there are also differences in other forms of descent which is to bring houses and trees in a much smaller size such as miniature, which is also inversely proportional to the size of the reference. The reference, but the application was rejected by We Cudaik depicting love can not only be valued with treasure alone.

\section{3) Kitsch}

Based on Eco, kitsch is an attempt to make art, development kitsch inseparable from the development of mass consumption and culture [5]. Therefore, as with parody, kitsch is a stylemes for the sake of its image. But different from parody whose production is based on a spirit of criticism, play (play), production kich based more on the spirit of reproduction, adaptation, and simulation. Production kitsch is based more on the process of counter the myths of art values. Ktsich adapt from one medium to another or from one type of art to another type of art.

Kitsch symptoms can occur in several ways: first, the transfer of one element or the totality of elements in a work of art or literature from their original status and context as high art and is used with its new status and context as mass culture. Second, the borrowing of certain elements of consumer goods removed from their original context and 
status as mass products and transferred to their context and status as 'high art'. Third, imitation of materials, namely the use of artificial materials to give effect and the impression of natural ingredients. Fourth, the transformation and idolization of icons, symbols, or symbols of sub-cultural objects and cultural objects into art objects and consumer goods. Fifth, objectification of myth, namely perpetuation of mythical objects or figures or who have become myths in the form of art objects or consumer goods p.196-197 [5].

Kitsch idiom works seem to assume a rare object and at the same time popularize the cultural values of the object. This aesthetic idiom gives place to various forms of reproduction and recycling through re-contextualization and reinterpretation.

Sureq galigo is the biggest literature in the world, a folklore owned by the Buginese community, but only known by the Buginese people themselves. Then the stories were brought to the stage into a theater performance by Robert Wilson so that the galigo sureq could be known by the entire world.

In the show I La Galigo promoting the form of new and simple and easy to digest by the community and in accordance with current needs. Where before sureq galigo This is in the form of lontara writing that can only be seen by certain people.

\section{4) Camp}

"Camp is a contradictory aesthetic idiom that is often associated with the formation of meaning, or poverty of meaning" p.221 [5]. Quoting Susan Sontag, Piliang said camp as a model aestheticism, which is a way of seeing the world as an aesthetic phenomenon, but not in terms of beauty or harmony, but rather artificiality and styling Estetism is something that can be seen positively in development style because of his rebellion against style of High Cultural elite p.222 [5].

Camp which rejects the authenticity or originality, is a form of duplication for its own purposes and interests as bricolage par-exellence, "Produce something from what is already available" with the basic ingredients of daily life, or rather fragments in real life, which are mixed and distorted to be unlike the original, become artificial. Emphasis camp not the uniqueness of a work of art, but the excitement of reproduction and distortion. Camp uphold abnormalities and unusual 222-223 [5]

In the camp work natural, human, and animal objects are often used, but they are extreme deformed, such as being made to appear thinner, leaner, tall, big, and wide which is anti-natural. Camp was created as an answer to boredom, it provided an illutive way out of poverty of meaning and filled it with sensations of abnormality and originality p.198 [5].

I la galigo theater performances are contemporary theater performances that are not only shows that are created and performed by humans today, but shows that reflect freedom. Its form is an experimental performance, which is an attempt to search for new idioms and pronunciation languages. In a theater performance I La Galigo One of the camp idioms is manifested in the first scene which is about the creation of the middle world, this scene illustrates the process of the formation of inner life 3 dimensions of time. The upper world and the underworld, the place of the gods, the middle world which is still empty and then filled by the eldest sons of the nobles of the upper and lower worlds. The beginning of the emergence of life in the middle of the world was revealed by the first man, the teacher Batara who emerged from the upper world Through the Bamboo Ladder creates a vertical line for the descendants of the Guru Batara from Above to Middle World in the position of the head below and feet above depicts the symbol of birth. Then sent down animals with various forms but do not resemble the original form, only using certain symbols with various forms and different levels. Likewise in other scenes present an artistic visual form that has been distorted to be not like the original. In the show also almost always takes place in two or multiroom interconnected with one another. Each of them creates events either through one character cast with another, electronic visuals and various moving objects. Performing in a design through understanding the stage is not a single event, where space no longer has a historical identity.

\section{5) Schizophrenia}

In culture and art, schizophrenia is used as a metaphor to describe the confusion of language use. The confusion of sign is in images, text, objects, and even sentences. Postmodern schizophrenic language is a language that results from the confusion of markers, styles, and expressions in a work, which results in contradictory, ambiguous, fragmented or vague meanings p.205 [5]. In works of art, schizophrenic works can be seen from the interrupted dialogue between the elements in the work, that is, the elements are not related to each other, so the meaning of the work is difficult to interpret. idiom schizophrenia it might say that it is water and fire, that it is traditional and modern.

The big idea of I La Galigo theater show is seen from a western perspective but the element in it is Indonesian culture from southern Sulawesi. This show includes contemporary theater performances that are very minimal in dialogue, so that there are many body movements that require a lot of interpretation, both of which can be interpreted in relation to the culture from the origin $I \mathrm{La}$ Galigo itself or universally interpreted from the body movements performed by the characters in the theater.

One of them is the use of the actor's body in this show is in the visualization of the sailing ship used by the Sawerigading to sail to China is an amalgamation of the bodies of the actors to form a ship. The scenes of these body movements are included in non-verbal communication. It is often used to describe feelings and emotions. Acting no longer prioritizes verbality and natural motion but in this show acting has another side which is called acting that experiences denationalization and runs interactions that different. So that the use of verbal and natural interaction is very limited. If the message received through the verbal system does not show the strength of the message then can accept other non-verbal signs as a support. Not only that, the effort to develop this $I$ La Galigo theater combines Bugis tradition and folklore with contemporary theater language.

\section{CONCLUSION}

Postmodern aesthetics are forms of rebellion from the standard rules of aesthetic modernism. According to Piliang, 
"the process of the production and signs of the process of semiotic in consumer societies and their application to the aesthetic discourse of postmodernism reflect that signs and meanings in postmodern aesthetics are unstable, dualism, and plural, due to the prioritization of sign games, fascination on the surface and divergence, from ideological meanings which are stable and lasting ".

I La Galigo theater performance has a postmodern aesthetic in which the idioms are contained pastiche, parody, kitsch, camp, and schizophrenia. This is how the postmodern aesthetic looks at the theater I La Galigo can be stored the following: First, aesthetics pastiche, manifestation as a "sureq galigo aesthetic idiom which is a source of adaptation of the I Lagaligo Theater performance which is realized on the stage of the show can be said to aim at the appreciation of postmodern art (culture) for its reference as a form of cultural tradition by reproducing it back to the present cultural context. Second, parody aesthetics, being "aesthetic idioms." cultural criticism of Siri", Which is a form of representation of emphasis difference relations with its reference, which aims at cultural reproduction and at the same time criticizing social life in society. Third, aesthetics kitsch, form as This aesthetic idiom provides a place for various forms of reproduction and recycling (recycling) through the re-contextualization and reinterpretation of epic literary works onto the stage. The I La Galigo showpromoting the form of new, simple and easy to digest by the community and in accordance with current needs. Before sureq galigo, this is in the form of lontara writing that can only be read by certain people. Fourth, aesthetics camp, form as an aesthetic androgin character ", which is a form of deformation or denationalization identity on the character of the role, and subverts extreme reference through social agreement, especially as the meaning of post-feminism that regenerates postmodernism. Fifth, aesthetics schizophrenia, as aesthetic as a language game schizophrenic", which is one of the tendencies of postmodernism which is deconstructive. Schizophrenia is understood as a break in the sign chain that constructs a language expression so that it is unable to produce definite meaning because of the overlapping of various categories in a performance text. The relationship between the marker and the sign has been interrupted or even completely cut off so as to produce fragments without clear markings. So that there are many body movements that require a lot of interpretation, both of which can be interpreted in relation to the culture from the origin of I La Galigo itself or universally interpreted from the body movements performed by the characters in the theater.

\section{REFERENCES}

[1] Sachari, Agus. "Estetika: Makna. Simbol dan Daya [Aesthetics: Meanings, Symbols and Power]." Bandung: Penerbit ITB (2002).

[2] Baudrillard, Jean. "The Ecstasy of Communication/The antiaethtetic Essey on postmodern culture/Translated by John Johnston." (1983): 45-96.

[3] Cohen, Matthew Isaac. "I La Galigo (review)." Asian Theatre Journal 22.1 (2005).

[4] Ratna, Nyoman Kutha. "Teori, Metode, dan Teknik Penelitian Sastra [Theories, Methods and Techniques of Literary Research]". Cetakan ketiga. Yogyakarta: Pustaka Pelajar (2007).

[5] Piliang, Yasraf Amir, and Alfathri Adlin. Hipersemiotika: Tafsir Cultural Studies atas Matinya Makna [Hypersemiotics: Cultural Studies Interpretation on the Death of Meaning]. Jalasutra, 2003.

[6] Piliang, Yasraf Amir. "Hiper-Realitas Kebudayaan: Semiotika, Estetika, Posmodernisme [Cultural Hyper-Reality: Semiotics, Aesthetics, Postmodernism]." Yogyakarta: Penerbit LKiS (1999).

[7] Suryajaya, Martin. "Sejarah Estetika [The History of Aesthetics]." Jakarta Barat: Gang Kabel (2016).

[8] Abidin, Yusuf Zainal. "Filsafat Postmodern [Postmodern Philosophy]." Bandung: CV Pustaka Setia (2018).

[9] Grenz, Stanley J. "A Primer On Postmodernism Pengantar untuk Memahami Postmodernisme". Yogyakarta: Yayasan Andi (2001).

[10] Ahmed, Akbar Salahudin, M. Sirozi, and Ilyas Hasan. Posmodernisme: bahaya dan harapan bagi Islam. Mizan, 1994.

[11] Kern, R. "I La Galigo: Cerita Bugis Kuno (I La Galigo: Ancient Bugis Stories)(L. Side and MD Sagimun, Trans.)." Jakarta: Gadjah Mada University Press, Koninklijk Instituut voor de Taal-, Land-en Volkenkunde (KITLV)-LIPI (1989). 